\title{
Transnacionalismus a kritika metodologického nacionalismu
}

\author{
Csaba Szaló
}

\section{Transnationalism and the Critique of Methodological Nationalism}

\begin{abstract}
If sociology of transnationalism is to remain innovative as a branch of knowledge, it should be able to encourage a reflexive analysis of its own critical projects. Theories of transnationalism both focus on transnational phenomena and explore the ways how national phenomena is theorized in social science. The former offers promises for understanding how social conditions and cultural processes constitute transnationality. The latter allows theories of transnationalism to capture the way in which relations of domination are encoded into conceptual frameworks and theoretical perspectives of academic discourse. I have focused here on theoretical dilemmas generated by the critique of methodological nationalism. The hermeneutic reconstruction of the first attempts to analyze methodological nationalism in the 1970s, I have carried out here, put emphasis on three attributes of this early critique: Firstly, it focused on the argument that methodological nationalism is necessarily interrelated with a particular theory of social change which accentuates the immanent dynamics of society. Secondly, it payed attention to a theoretical dilemma resulting from conceptualizing nations as social units. Thirdly, it addressed itself to the theoretical dilemma of conceptualizing the nation-state beyond methodological nationalism. By taking seriously reconstructive interpretation of earlier form of critique of methodological nationalism, this text fully recognizes the importance of theoretical logic in sociology and conceives the question of methodological nationalism in terms of a conflict between alternative theoretical frames.
\end{abstract}

KEY WORDS methodological nationalism, transnationalism, social change, nation-state.

Sociologické a antropologické teorie transnacionalismu jsou úzce spojeny s progresivní snahou kritické sociální teorie formulovat nové analytické koncepty relevantní pro současný globalizující se svět. Zdá se však, že tuto snahu nejde oddělovat od emancipace sociální vědy od jejích nacionalistických předpokladů. Dnes se kritika metodologického nacionalismu povětšinou přijímá jako konstitutivní část transnacionalistického výzkumného paradigmatu (Levitt, Jaworsky 2007; Wimmer, Glick Schiller 2002a). Abychom pochopili epistemologickou funkci této kritiky, je třeba si uvědomit, že teorie transnacionalismu - především transnacionální migrace - nelze zařazovat čistě do kategorie empiricko-analytických věd. Většina těchto teorií sleduje metodologickou dráhu interpretativních věd a pomocí interpretativních strategií, které by mohly být označeny jako hermeneutický rekonstrukcionismus, získává

Sociální studia. Fakulta sociálních studií Masarykovy univerzity, 1/2009. S. 49-68. ISSN 1214-813X. 
kritickou funkci. V první části tohoto textu vysvětlím onu interpretativní strategii a v druhé se podrobněji zaměřím na ranou fázi kritiky metodologického nacionalismu, která se vyvinula v sedmdesátých letech 20 . století.

Celkovým cílem tohoto textu je rekonstrukce konceptuálních rámců a teoretických předpokladů, které sdílejí teorie transnacionalismu a raná sociologická kritika metodologického nacionalismu. Klíčovým bodem článku, který rozvíjím ve třetí části, je tvrzení, že současná kritika metodologického nacionalismu, jež chce mít empirické základy v transnacionalismu, je ve skutečnosti konstruována na základě témat, konceptů a teorií první fáze kritiky metodologického nacionalismu rozvíjených $\mathrm{v}$ sedmdesátých letech 20 . století (a během debaty o globalizaci v letech osmdesátých), kterým se již úspěšně podařilo rekonstruovat základní koncepty - stavební kameny - metodologického nacionalismu. Konstruktivním záměrem následujícího textu je analyticky rozlišit teoretickou a historickou verzi kritiky metodologického nacionalismu. Toto rozlišení může nabídnout odpověd’ na některá teoretická dilemata, s nimiž se setkáváme při pokusech o konceptualizaci vztahu mezi metodologickým nacionalismem a jeho překonáním z perspektivy transnacionalismu.

\section{Kritická funkce transnacionalismu}

Narozdíl od empiricko-analytických věd - jejichž cílem je pozorovat vnímatelnou skutečnost a vynalézat nomologické hypotézy vztahující se $\mathrm{k}$ dané pozorované oblasti - je cílem interpretativních/rekonstruktivních věd pochopení symbolicky před-strukturované reality. Získávání teoretických poznatků zde postupuje pomocí ozřejmování praktického vědění (know-how) subjekti̊. Podle Habermase (1991: 9) se tyto vědy utvářejí okolo procedur, které „systematicky rekonstruují intuitivní vědění kompetentních subjektư“. Důležitým rysem jak antropologických, tak sociologických teorí transnacionální migrace je, že berou vážně předteoretické vědění subjektů, tedy že pojímají transnacionální migranty jako kompetentní subjekty, a také tak s nimi zacházejí (Kearney 1991). Kompetence těchto subjektů je chápána především, jak už bylo řečeno, coby jejich intuitivní vědění ztělesněné v jejich jednání, úsudcích a jazyku, a dále také jako vědění předávané kulturami, které pořádají jejich žitý svět.

Dřive než se pustím do obecného popisu kritické funkce transnacionalismu, upozorním na odlišnost způsobů, jimiž se interpretativní/rekonstruktivní vědy a empiricko-analytické vědy vztahují ke každodennímu vědění sociálních aktérů. Z hlediska klasické metodologie humanitních věd (Polkinghorn 1983: 215-240, 251-252) spočívá tento rozdíl v tom, že zatímco empiricko-analytické vědy standardně odmítají jak praktické vědění subjektů, tak vědění vznikající $\mathrm{v}$ rámci kulturních praktik, interpretativní vědy tyto před-teoretické formy vědění nefalsifikují, jen je ožrejmují a systematizují. Avšak z habermasovské perspektivy kritické sociální teorie by druhý prrístup představoval pozici radikální hermeneutiky, která se vzdává nároku na objektivní a vysvětlující vědění. Interpretativní strategie hermeneutického rekonstrukcionismu přijímá fakt, že „nevyhnutelné zapojení interpretujícího do procesu dosahování porozumění jej ve skutečnosti zbavuje privilegovaného statusu objektivního pozorovatele... ale ze stejného důvodu mu také umožňuje udržet si vyjednanou vnitřní nestrannost“ (Habermas 1992: 29). Kompetence, kterou interpretující takto získává z komunikativní situace, je základem kritické funkce rekonstruktivní interpretace. 
Nabízí se říci, že takovýto kritický př́stup vyžaduje rekonstrukci implicitního knowhow a kulturně předávaného vědění sociálních aktérů, nicméně jde zde o víc než o tuto hermeneutickou rekonstrukci. ${ }^{1}$ Každopádně nelze opustit „pouhou rekonstrukci“, a tím, že ji vynecháme z našeho př́stupu, dosáhnout kritické pozice. Spíše než přeskočit rekonstrukci je třeba z ní učinit východisko kritické perspektivy. V tomto smyslu lze kritickou funkci hermeneutického rekonstrukcionismu rozdělit do dvou metodologických kroků. Za prvé, aby interpretující chápal nějaký text, musí činit rozhodnutí a závěry, které mu umožní stanovit důvody, proč tvrzení a výroky autora vykazují znaky, na jejichž základě mohou být přijímány jako pravdivé, správné a autentické pro autora samotného (Habermas 1992: 29-31). Tímto způsobem musí interpretující rekonstruovat kulturní kontext, který autor předpokládal jako přijatelné [prijímané] vědění sdílené se zamýšlenými čtenáři. Avšak důvody ospravedlňující autorovy nároky na prijjatelnost a platnost lze chápat pouze $\mathrm{v}$ prŕpadě, že je bereme vážně jako důvody, které mohou být hodnoceny, tj. $\mathrm{v}$ určitých př́padech zneplatněny/zamítnuty. Jakákoliv interpretace je racionální interpretací pouze tehdy, když je založena na racionální rekonstrukci know-how autora a jeho předpokládaných čtenářŭ, to znamená subjektů schopných rozlišovat mezi platnými a neplatnými tvrzeními. Za druhé stejně jako kompetentní subjekty, které dokáží činit podobná rozhodnutí na základě svého před-teoretického vědění, také interpretace založené na hermeneutické rekonstrukci tohoto před-teoretického vědění umožňují rozlišovat mezi platnými a neplatnými tvrzeními, a tak rovněž získávají kritickou funkci.

Navážu-li na výše řečené, pokud jsou teorie založené na hermeneutické rekonstrukci schopny chápat a vyjasňovat podmínky pro platná/přijatelná - bereme-li v úvahu pravdivost, správnost a autentičnost - tvrzení, mohou také vysvětlit, proč jsou určitá tvrzení (a argumenty) nepřijatelná. Tento kritický potenciál pak dovoluje antropologickým a sociologickým teoriím zaštítit kritické výroky o sociálních, politických a kulturních praktikách. ${ }^{2}$ Proto tyto teorie, včetně teorií transnacionální migrace, také činí srozumitelnými jak sociální podmínky, v nichž se transnacionální procesy odehrávají, tak kulturní procesy utváŕení významu a identit, které s nimi souvisejí. Kritické teorie transnacionalismu nemohou ignorovat analýzu způ-

$\mathrm{K}$ alternativnímu pokusu o osvětlení kritického potenciálu interpretativních věd viz Brubaker et al. (2004). Jejich text prosazuje kognitivní studium rasy, etnicity a národa jako způsobů vidění, nahlížení světa, nikoliv jako př́islušnosti ke skupině. Následně pak mají rasa, etnicita a národ v sociální realitě konstitutivní funkci ve smyslu realitu utvářejících sil kolektivních kulturních reprezentací. Brubaker a spol. přiznávají důležitost praktickému vědění subjektů a soustředí se na „lidovou sociologickou ontologii, která je středem rasových, etnických a národních hnutí“ (2004: 5), ale odmítají analytickou aplikaci praktického vědění subjekto̊ jako neadekvátní. Jejich kritický př́stup zdůrazňuje nutnou distanci a rozdíl mezi analytickými a praktickými formami vědění. Takto lze analyzovat „primordialitu aktérü“, aniž bychom prosazovali „,analytickou primordialitu“, tj. aniž bychom se podřizovali tendenci praktického vědění naturalizovat a esencializovat rasové, etnické a národní kategorie (2004: 50). K rozdílům mezi habermasovskou, bourdieuovskou a foucaultovskou verzí kritické sociologie viz Bourdieu, Wacquant (1992: 47-59).

2 Striktní interpretace hermeneutického rekonstrukcionismu tvrdí, že tímto způsobem je kritika schopna ukázat, jak sociální praktiky porušují/překračují nejen pravidla přijímaná v určitém sociálním kontextu, ale také univerzální podmínky racionality. 
sobů, jimiž jsou kulturní významy používány k zakódování a reprodukci vztahů nadvlády. Coby výsledek reflexivního obratu $\mathrm{v}$ antropologii a sociologii jsou teorie transnacionalismu obzvláště vhodné ke zkoumání způsobů, jimiž označující praktiky vytvářejí ideologický účinek dokonce i v institucionální sfére vědy. Kritické teorie transnacionalismu se totiž nezabývají pouze před-teoretickým věděním transnacionálních migrantů, ale snaží se rekonstruovat koncepty, pravidla, kritéria a schémata, která pozorovatelé a výzkumníci používají ve svém výzkumu transnacionálních migrantů.

Jelikož transnacionalismus se dnes jeví jako konstitutivní prvek modernity, a nikoliv pouze jako aktuální důsledek globalizačních procesů, kritické ohnisko teorií transnacionalismu se obrátilo ke zkoumání konceptuálního aparátu hlavního proudu sociální vědy, především toho, jakým způsobem ovlivnila tato věda studium migrace a nakolik obecně zanedbávala transnacionální jevy (Wimmer, Glick Schiller 2002a). Skutečnost, že moderní svět byl vždy světem transnacionálním, byla podle této kritiky zakrývána především empiricko-analytickým zaměřením metodologického nacionalismu.

\section{Genealogie kritiky metodologického nacionalismu}

\section{Metodologický nacionalismus a jeho současná kritika}

$\mathrm{V}$ základní formě najdeme metodologický nacionalismus $\mathrm{v}$ textech, které chápou národní stát jako přirozenou a nutnou formu moderní společnosti. Z hlediska metodologického nacionalismu jsou společnost a národní stát konceptuálně neodlišitelné. Vize „národní společnosti“ navíc předpokládá princip mezinárodnosti. Národní společnost je myslitelná pouze $\mathrm{v}$ mezinárodním prostoru utvářeném pluralitou států, které odpovídají národům/lidům. Tento konceptuální rád národnosti a mezinárodnosti může být podle Ulricha Becka (2006: 62-66) postaven do protikladu vǐči řádu utváŕenému kolem konceptů transnacionality a kosmopolitismu. Řečeno Beckovými slovy (2006: 62-63): „Transnacionalita označuje formu života a praxe, která nahrazuje národní ,bud', anebo“ sou-národním ,a zároveň`. Sou-národní (tedy ne-národní) formy života, myšlení a praktik, které neuznávají hranice mezi státy, jsou transnárodní.“

Metodologický nacionalismus je tak v současnosti zpochybňován novými zkušenostmi a kategoriemi vzájemné závislosti. Beck (2006: 62-66) tvrdí, že zažíváme zrození nových, hybridních sociálních a kulturních forem, pro něž konceptuální řád národnosti a mezinárodnosti - fungující v logice, podle níž se každý a všechno klasifikuje jako bud' náležející k nám, nebo náležející $\mathrm{k}$ jiným - nemá jméno. $\mathrm{V}$ důsledku toho nejen jevy transnacionalismu, ale také konceptuální rozlišení mezi národním a transnárodním musí být chápány pomocí logiky a/zároveň. Např́íklad když transnacionalismus zahrnuje procesy oddělení občanského statusu od místa pobytu, neznamená to nutně, že národní způsob slučování občanství s trvalým pobytem občanů $v$ jejich zemi je definitivně u konce. Deteritorializace občanství jako forma transnacionalismu vytváŕí praktiky vyvažování/stabilizace mezi různými politickými loajalitami. Avšak zahrnuje jak mnohočetnou př́slušnost, tak národnost. Kategorie transnacionálního nacionalismu je dobrým př́kladem rozkladné moci transnacionalismu, který přináší zmatek do konceptuálních dualit metodologického nacionalismu. Transnacionální migranti nejsou nutně $\mathrm{v}$ protikladu $\mathrm{k}$ nacionálním domorodcům. Transnacionální migranti mohou být také 
nacionalisté, navzdory faktu, že podmínky jejich existence v určitém ohledu narušují konceptuální rád nacionalismu. ${ }^{3}$

Kritika metodologického nacionalismu má původ v reflexivní sociologii sedmdesátých let 20. století, kdy několik britských sociologů - Herminio Martins, Anthony Giddens a Anthony D. Smith - přišlo s kritickými argumenty, které zavrhovaly neproblematický metodologický př́stup současných sociálních věd ke společnosti/národnímu státu, jako by šlo o svébytnou, autonomní a uzavřenou jednotku zkoumání. V tehdejších diskusích šlo především o to, že nereflexivní, nacionalistická a neadekvátní vize svébytné společnosti připravila půdu pro endogenní teorie sociální změny. Jinými slovy kritika metodologického nacionalismu vznikala jako vedlejší produkt kritického diskursu, který se primárně zabýval formulací vhodné sociologické teorie sociální změny.

Od začátku osmdesátých let 20 . století ustavil sociologický diskurs o globalizaci několik perspektiv, které začaly zpochybňovat základní roli národního státu při strukturování sociologické imaginace. Podle Brennera (1999: 40) se tato metodologická „snaha transcendovat státo-centrické epistemologie“ stala ústředním tématem globalizačního diskursu. Kritika metodologického nacionalismu, tak jak vykrystalizovala $\mathrm{v}$ osmdesátých a devadesátých letech 20. století, obvykle odhaluje dva epistemologické předpoklady státo-centrismu: (a) Prostorový fetišismus. ${ }^{4}$ Jde o pojetí prostoru jako bezčasého, statického pódia sociálního jednání. Fetišismus zdůrazňuje ahistorickou povahu tohoto pojetí; prostor tedy není chápán jako sociálně konstruovaný - jinými slovy neuvažuje se o něm jako o objektu historické změny. (b) Metodologický teritorialismus. ${ }^{5}$ Jedná se o předpoklad souladu mezi převládajícím měřítkem sociálně vědní analýzy a moderním teritoriem národního státu. Metodologická povaha tohoto předpokladu spočívá ve skutečnosti, že je schopen pojímat a analyzovat všechny sociální formy, jako by šlo o do sebe uzavřené a teritoriálně propojené geografické jednotky. Jinými slovy ztotožňuje společnost $\mathrm{s}$ teritoriem/populací národního státu.

Klíč k tomuto vývoji lze najít v „prostorovém obratu“ v kritické sociální teorii, totiž v rostoucím zájmu o geografii, teritorialitu a roli prostoru v sociálních procesech (Soja 1989: 6-8). ${ }^{6}$ Právě v souladu s touto kritickou reinterpretací prostoru odkryl globalizační diskurs $\mathrm{v}$ základech státo-centrických př́stupů ahistorickou prostorovou ontologii, která

K rozdílům mezi transnacionálním nacionalismem a diasporním nacionalismem viz Kastoryano (2007: 165-166).

4 Pojem prostorového fetišismu má původ v kritice urbánní sociologie Manuela Castellse (2002 [1977]) a v jeho kritice Henriho Lefebvra a jeho analýzy prostorových mocenských praktik pojímaných jako konstrukce a rušení rozdílů. Castells tvrdil, že je nutné se povznést nad iluzi, že námi pozorované dění ve městech je produktem měst. Jak ukázal také ve svých pozdějších pracích (Castells 1997, 2000), pro sociologii není tolik důležitý prostor jako místní sociální prostředí, ale spíše procesy, které se vyskytují např́íc prostorem.

5 Koncept metodologického nacionalismu zavedl Jan A. Scholte (1992: 9-22, 2000: 56).

6 Prostorové iluze naturalismu a historismu již do hloubky kritizovali v 70. letech Henri Lefebvre (1998) a Michel Foucault (2000: 175-185, 2007: 173-182). Kritické př́stupy takzvaného prostorového obratu v současné sociální teorii staví na jejich - Lefebvrově a Foucaultově - konceptuální strategii kritiky. Stručně řečeno jak Foucault, tak Lefebvre rozpoznali prostorovost zároveň jako sociální produkt a formativní médium sociální reality. 
pojímá „prostor jako nádobu“ (Brenner 1999: 45). Část diskursu o globalizaci prováděla svou analýzu globálních procesů $\mathrm{v}$ duchu metodologického nacionalismu, pouhým rozšiřováním rámce státo-centrické teritoriality na globální měřítko. Avšak během devadesátých let 20. století se alternativní prrístup soustředěný kolem teorie „deteritorializace“ utkal s touto výzvou - kritikou modelu prostoru jako nádoby - tak, že pojal globalizaci jako teritoriálně neukotvené procesy zahrnující erozi národního státu. ${ }^{7}$ Globální sítě a toky podle této perspektivy nahrazují teritoriální geografii národních států založenou na hranicích a nehybných místech. ${ }^{8}$

Diskurs transnacionalismu, který se ustavil $\mathrm{v}$ devadesátých letech 20 . století z problematizace vztahu mezi národním státem a migračními procesy, do jisté míry sledoval logiku deteritorializačních př́stupů a tvrdil, že současný trend transnacionální migrace přináší nové formy sociálních vztahů (Bash et al. 1994: 268-272). Nicméně už v době svého utváření obsahoval diskurs transnacionalismu kritiku hlavního proudu sociálních věd kvůli jeho opomíjení ústřední role migračních procesů $\mathrm{v}$ celé moderní historii, oné historii národního státu. Takto transnacionalismus udržuje naživu epistemologickou verzi kritiky metodologického nacionalismu, která není nutně založena na empirickém zkoumání vznikajících historických jevů. Jinými slovy transnacionalismus představuje př́ležitost překonat falešnou dichotomii mezi současným boomem proudů, sítí a tekutosti na straně jedné a zcela nehybným územním národním státem na straně druhé (Wimmer, Glick Schiller 2002a; Levitt, Schiller 2004).

Wimmer a Glick Schiller (2002a, 2002b, 2003) ve své průlomové práci rozlišují tři složky metodologického nacionalismu - přehlížení, naturalizaci a teritoriální omezení -, které „vytvářejí koherentní epistemickou strukturu, způsob nahlížení a popisování sociálního světa, který posiluje sám sebe“ (2002a: 308). Podobně jako jejich rekonstruktivní kritika založená na uznání důležitosti historické epistemologie, pokusí se následující stránky rekonstruovat historicky dané epistemologické předpoklady kritiky metodologického nacionalismu, tak jak se objevovaly v 70 . letech 20 . století.

\section{Metodologický nacionalismus a přehližení transnacionálních jevů}

Na začátku 70. let 20. století zavedl Herminio Martins (1974: 276-277) ve svém textu věnovaném analýze pojímání času v současné sociologické teorii termín „metodologický nacionalismus", aby reflektoval podřízenost makro-sociologických teorií národním před-definicím sociální reality. Pro Martinse (1974: 284-285) představoval koncept metodologického nacionalismu důležitý prvek základní konceptuální reflexe - kritiky základů a převládajících předpokladů -, kterou si tehdejší hluboká krize sociologie žádala.

Podobně jako jiní sociologové (Gouldner 1970, Smart 1976: 104-107) Martins (1974: 284-287) rovněž prosazoval „reflexivní sociologii“ jako východisko ze současné krize sociologie, a navíc tvrdil, že reflexivita je inherentní epistemologickým podmínkám, které umož-

$7 \quad$ K deteritorializaci viz Appadurai (1997), Castells (1997: 243-309), Jameson (1995), Gupta a Ferguson (1997). Samotný koncept má původ v radikálních teoriích, které Paul Virilio (1986) a Deleuze and Guattari (1988) vypracovali na konci 70. a v začátku 80. let 20. století.

8 V rámci mainstreamové sociologie šířil myšlenku, že globalizace značí také úpadek národního státu především Castells (1997, 2000), Beck (2000), Albrow (1997). 
nily vznik sociologie. Sociologická analýza ve své základní formě musí postupovat pomocí reflexe předem daných konstruktů sociální reality. Jinými slovy sociologická interpretace je nutně způsobem tázání druhého řádu, nebot' utváření sociální reality není možné bez typifikací a symbolických významů sociálních aktérů, kteří v tomto sociálním světě žijí. Nicméně toto specifikum sociologie spočívající v tom, že negeneruje vědění nevědomých bytostí, ale zaměřuje se na vědění vědoucích bytostí, vede k nevyhnutelnosti reflexivní kritiky svých vlastních konceptuálních, teoretických a metodologických základů.

Martins (1974) odkrývá dva zamlčené předpoklady sociologické teorie: princip metodologického nacionalismu doprovázený principem ,imanentní změny“. 9 Druhý z principů předpokládá, že společnosti procházejí neustálou změnou, přičemž tato změna se vztahuje na systémové modifikace nebo transformace jejich vnitřních vlastností. Tento předpoklad ústí v „monadologické“ hledisko, které společnosti představuje jako diskrétní jednotky analýzy. Jevy a události, které se odehrávají bud' mimo rámec jednotlivých společností, nebo mezi společnostmi, jsou pak nutně pokládány za nahodilé a náhodné, zatímco vnitrospolečenské jevy jsou považovány za přirozené a esenciální. Princip imanentní změny však nutně neznamená změnu generovanou vnitřními faktory; změna může být působena vnějšími okolnostmi, zasahujícími událostmi. Důležitější však je, jak si všímá Martins (1974: 277), že v této konceptualizaci chybí události zasahující vnější prostředí společnosti. Princip imanentní změny tak znemožňuje teoreticky uvažovat o společnosti a jejích prvcích jako o něčem, co může generovat nepředvídané změny v jejím sociálním milieu.

Princip metodologického nacionalismu, coby další skrytý předpoklad, je pro Martinse (1974: 276) přítomný v rozšířeném názoru, že společnost - ve skutečnosti národní stát - by se měla pokládat za standardní a optimální objekt sociologické analýzy. Společnost pojímaná jako národní komunita je v tomto smyslu považována za „konečnou jednotku a hraniční podmínku pro vymezení problémů a jevů sociálních věd“ (Martins 1974: 276). Metodologický nacionalismus nejde $\mathrm{v}$ prrípadě jednotlivých sociologů nutně ruku v ruce s politickým nacionalismem, přesto je politický nacionalismus v těchto př́padech přítomen ve svých metodologických důsledcích. Takové důsledky omezujících, nacionálních/nacionalistických před-definicí sociální reality Martins (1974: 276) ilustruje na př́kladech migrace pojímané metodologicky nacionalistickým způsobem.

Sociologické a antropologické studie migrace se povětšině zaměřují na imigraci. Navzdory skutečnosti, že každý imigrant je z definice také emigrantem, omezující povaha metodologického nacionalismu stále vědcům zabraňuje pojednávat imigranty zároveň jako emigranty a emigranty jako imigranty. ${ }^{10} \mathrm{Z}$ hlediska metodologického nacionalismu se téma migrace stává sociologicky relevantním kvůli jejím důsledkům v národních společnostech zažívajících masové migrace. A tak je obecný proces migrace pojímán a zkoumán v hostitelské společnosti sociology patř́cími k této společnosti, a to pouze jako proces imigrace.

9 Termín samotný - princip imanentní změny - pochází ze Sorokinovy proslulé Sociální a kulturní změny (Social and Cultural Change), publikované na konci 30. let 20. století.

10 Existuje ne-nacionalistický směr studia migrace, kterého si všímá také Martins, jejž otevřeli Thomas a Znaniecki svou knihou Polský rolník v Evropě a v Americe (The Polish Peasant in Europe and America). 
Jinak řečeno hluboce zakořeněné konceptuální zájmy a metodologické směřování vytvářejí metodologickou nacionalistickou perspektivu migrace. Někdy napríklad, jak ukazuje př́ípad teorie mezinárodního systému, metodologický nacionalismus pouze přetlumočí klíčové principy metodologického individualismu: představuje národní státy, jako by to byli racionální hráči nebo normativně orientovaní sociální aktéŕi. Martinsova (1974: 277) kritická interpretace jde dále než současná kritika těchto teoretických předpokladů, která vznesla námitky proti interní homogenizaci společností, které jsou pojímány jako racionálně nebo normativně ,jednající“ aktéři. Jeho kritika nevolá pouze po přesunu důrazu na vnitřní konflikty a vnitřní pluralitu společností. Martinsovo pojetí a kritika metodologického nacionalismu se explicitně zaměřují na „opomíjení transnacionálních jevů jako takových“ (1974: 277). Co se týče teoretických předpokladů, je Martinsova kritika metodologického nacionalismu založena na myšlence, že spíše než uzavřená monáda soběstačnosti a imanence je vhodnějším modelem pro porozumění sociální realitě transakční pole.

\section{Metodologický nacionalismus jako rámec nacionalistického myšlení}

Ve své knize o nedělitelnosti státní moci a nacionalistického myšlenkového rámce Nacionalismus ve dvacátém století (Nationalism in the Twentieth Century) vypracoval Anthony Smith (1979) novou interpretaci pojmu „metodologický nacionalismus“. Zatímco Martins (1974: 276) ještě trval na tom, že metodologický nacionalismus nutně nesouvisí s politickým nacionalismem, Smith (1979: 191) tvrdil, že v průběhu druhé poloviny 20. století institucionální a symbolické sjednocení státu a národa stále více ovlivňovalo vědecké obory, které studují moderní společenskou realitu. Nacionalismus podporovaný státem měl nevyhnutelnou kognitivní sílu, která prímo utvářela sociální vědy. V tomto smyslu se princip metodologického nacionalismu, podle něhož se studium společnosti rovná analýze národního státu, teoreticky zakládá na príijetí nacionalistických koncepcí. Metodologický nacionalismus může navíc posílit koncepce, které náležejí do oblasti politického nacionalismu. Analytické pojetí metodologického nacionalismu v tomto smyslu odhaluje skutečnost, že fragmentace světa do národních států se v současné době „stala trvalou a stabilní složkou našeho celého kognitivního systému, nehledě na psychologické uspokojení, jež skýtá" (Smith 1979: 191).

Politický nacionalismus národního státu se upevňuje prostřednictvím metodologického nacionalismu sociálních věd, protože chápání společnosti posiluje normativní ideu pevnosti a soběstačnosti národního státu. Metodologický nacionalismus je výsledkem téhož historického procesu, který vedl k rozšiření nacionalistického uvažování mezi politiky, intelektuály a byrokraty. Smith chápe vznik metodologického nacionalismu jako přímý důsledek stoupajícího vlivu politického/státního nacionalismu v průběhu 20. století.

Ve skutečnosti jde Smith (1983: 25-26) o několik let později ještě dále tvrzením, že vztah politického a metodologického nacionalismu je hlavním důvodem toho, že sociologie nacionalismus opomíjí: „neochota oboru tak zatíženého stejnými předpoklady, jaké mají objekty jeho studia, ustoupit stranou a uvědomit si svou historickou konkrétnost, zabránila sociologům až do nedávné doby věnovat pozornost objektu, který si ji jasně zaslouží - nacionalismu; $\mathrm{s}$ tím důsledkem, že růst národů a národních států a jejich etnického jádra, z něhož 
se většina sociologů běžně rekrutuje, jsou témata a rysy společností, které ,považujeme za dané‘; jsou součástí běžného myšlenkového vybavení, které si s sebou nesou ti, kdo společnost zkoumají, stejně jako jiní její členové.“

Smith (1983) podobně jako Martins (1974) volá po reflexivnějším typu sociologie. Avšak v jeho pojetí nespočívá posun k vyšší míře reflexivity pouze ve zviditelnění toho, co bylo zprvu bráno za samozřejmé. Smith chce, aby se sociologové distancovali od základních východisek sociologie, která jsou vlastně rovněž základními východisky nacionalismu. Ale co doposud znemožňovalo sociologii distancovat se od svých vlastních základních východisek? Příčinou nereflexivní situace sociologie je samotná povaha těchto východisek. Právě specifický způsob konceptualizace času, společenského řádu a společenské změny, zejména jejích evolučních teoretických předpokladů a z nich vyplývajících evolučních utopických tendencí, stále znemožňují současné sociologii distancovat se od těchto teoretických základů. Evoluční předpoklady, které stojí u základu sociologického uvažování, jsou zároveň základními teoretickými východisky nacionalistického myšlení. Historie pojímaná ve smyslu národního rozvoje je př́tomna jak v sociologii, tak v nacionalismu.

V tomto smyslu metodologický nacionalismus, který klade rovnítko mezi studium společnosti a studium národa/národního státu, úzce souvisí s evoluční, endogenní perspektivou společenské změny. Smith $(1973: 56,156)$ vidí za úspěchem této evoluční endogenní perspektivy neprrímý politický vliv národního státu. Pojímat společenskou změnu převážně jako proces vnitřního růstu znamená sdílet nacionalistický důraz na společenskou exkluzivitu a hranice národní komunity. Autarkní idea národní nezávislosti a důraz na vnitřní solidaritu tvoří součást nacionalistické vize společenské změny kontrolované uvnitř společnosti, která je kontrolována národním státem.

Smith (1973: 154-156) nalezl kořeny této „Zvnitřnující“ sociologické perspektivy (a) v nacionalistickém mýtu o endogenním původu a vývoji národa; (b) v etnocentrickém okcidentalismu, který vnímá západní dějiny jako jedinečný vývojový proud západní civilizace, založené čistě na endogenních faktorech. Navzdory jejich logické nesourodosti se tyto myšlenky vlastně vzájemně upevňují. Snadno najdeme nacionalisty, kteří jsou zároveň etnocentričtí Evropané v tom smyslu, že sdílejí myšlenku jak vnitřního národního růstu, tak jedinečnosti západní civilizace. Podobně můžeme v sociologické tradici nalézt myšlenkovou dualitu, která zdůrazňuje vnitřní dynamiku národnostně pojatých společností a jedinečnosti modernity pocházející ze Západu.

Smith (1973: 154-156) vysledoval sociální původ politického i metodologického nacionalismu v sekulární střední trrídě. Endogenní náhled na historickou změnu dodává této nové třídě, která vzniká s modernitou, ideologickou/intelektuální sebedůvěru založenou na přesvědčení, že dějiny jsou na její straně. Podle tohoto přesvědčení mají buržoazní střední třída i dějiny společnou dynamickou povahu, díky níž jsou schopny vytvářet samy sebe. Smith staví v tomto ohledu svou argumentaci na Camusově obrazu buržoazní identity a tvrdí, že jde právě o měšt’anský strach z náhody, který stojí u vize endogenní historické změny. Podle Camuse (1962: 161-165) sekularizovaná forma měštácké identity vysvobozuje individuální existenci z ,pout osudu“ vnímaných v náboženském pojetí. Avšak radikální interpretace tohoto osvobození - představa, že namísto osudu ovládá existenci náhoda - není přijatelná z buržoazního úhlu pohledu, který se zakládá na normativním principu hodnoty úsilí 
vyvinutého jedincem. „Zvnitřňující“ vize historické změny - ve formě buržoazního mesiášství Pokroku - poskytuje buržoazní identitě ochranu před rozložením osudu na náhodu.

Pro naše účely bude rovněž zásadní odhalit epistemologické kořeny této endogenní vize. Proč sociology tak dlouho přitahoval endogenní pohled na změnu? Asi nejpatrnější zdroj této perspektivy lze najít v organickém modelu změny, v evoluční představě rozvíjejících se možností (unfolding potentialities). Nicméně jak ukazuje Smith (1973: 26-59), v této přitažlivosti sehrály kritickou úlohu teoretická perspektiva funkcionalismu a široce sdílené pojetí systému. Konceptuální model systému představuje způsob, v němž je společnost pojímána - vysoce abstraktně a metaforicky - ,jako by“ byla organismem. Jinými slovy idea systému, který sestává z částic, jež jsou na sobě funkčně závislé, nutně přesouvá zřetel sociologické analýzy na vnitřní, relační strukturu společnosti. Na základě těchto předpokladů vychází moderní sociologie z představy o způsobu společenské změny coby přeměny vnitřní struktury dané společnosti. Navíc je tato strukturální přeměna chápána jako výtvor vzájemné závislosti jednotlivých součástí systému.

Důraz na vzájemnou závislost prvků společnosti eliminuje teoretický problém nahodilosti a náhodnosti, který byl obvykle spojován s externě pojímanou dynamikou změny (Smith 1973: 155). Normativní předpoklad na pozadí systémové analýzy společnosti slouží právě a výlučně $\mathrm{k}$ tomu, aby udržel náhodné události a procesy vytvářející změnu v mezích. Čili pod podmínkou, že změna je chápána jako funkce vztahů mezi souborem vzájemně závislých částí systému, se stává transformativním procesem vznikajícím kumulací efektů vnitřní společenské dynamiky. Smith přímo říká (1973: 155): „Změna se stává automatickou, stejně neoddělitelnou od ideje systému jako představa vzájemné závislosti, která ji produkuje. Změna leží uvnitř systému; přestože ji okolní prostředí může uspíšit, teoreticky je odvoditelná z vlastností každého systému."

Co plyne ze Smithových teoretických úvah? Za prvé kritika metodologického nacionalismu volá po „exogenním paradigmatu“ změny, stejně jako teorie kulturní difúze. Za druhé půjdeme-li v tomto smyslu za hranice metodologického nacionalismu, nejedná se pouze o otázku překonání duality vnitřní/vnější dynamiky změny, ale rovněž o teoretickou reflexi problému nahodilosti/pravidelnosti změny. Postmetodologické nacionalistické hledisko se tedy bude muset více zaměřit na chaos či na otevřenou strukturu. Přesáhnout metodologický nacionalismus neznamená pouze vystoupit z myšlenkového rámce „společnosti jako národní jednotky“; je potřeba opustit jak perspektivu endogenismu, tak perspektivu pravidelnosti.

Diskuse nad hlavními principy Smithovy kritiky metodologického nacionalismu dává nahlédnout do způsobů uvažování a do teoretického kontextu, v němž se tato raná fáze kritiky ustavovala. Důvodů zabývat se texty Anthonyho Smithe je však více. Jako zavedený teoretik nacionalismu byl Smith rozsáhle kritizován kvůli etnosymbolické interpretaci nacionalismu, která je ve svých normativních implikacích ve skutečnosti ospravedlněním nacionalistických ideologií (Ozkirimli 2003). Navzdory kritice metodologického nacionalismu v jeho raných pracích je tak Smithova teorie nacionalismu chycena v konceptuálním rámci stejného metodologického nacionalismu. Pokusy o teoretické shrnutí současné formy transnacionalismu tedy dilematicky čelí otázce, co se stane po změně vlastní teoretické perspektivy. Měli bychom se vyhnout užívání některých slov/konceptů, jako je „národ“, vyříznout je z našich 
interpretačních rámců, nebo je máme i nadále používat a co nejlépe se snažit je reinterpretovat, užívat nově?

Například ve své knize Koncept sociální změny (The Concept of Social Change) (Smith 1973), v níž se zabývá „Zvnějšňujícími“ teoriemi sociálních změn, které jsou alternativou kritizovaných „zvnitřnujících“ teorií, z nichž vychází metodologický nacionalismus, specifikuje jednotky, které jsou objektem sociální transformace, následovně: „daná konkrétní jednotka stát, kmen, město, národ nebo třída - je vždy složena z určitého počtu vzájemně propojených, ale nestejnoměrně se pronikajících vzorců opakujících se událostí...“(1973: 161). Zatímco „Zvnitřňující“ perspektiva se zaměřuje na vnitřní dynamiku sociálních jednotek, centrum pozornosti „Zvnějšňujícího“ přístupu lze vytyčit jako zasahování určité sociální jednotky do jiného sledu událostí. Podle výše popsaného př́stupu spočívá metodologický nacionalismus v analytickém ztotožňování společnosti s národním státem, ve Smithově pojetí s analytickým přijímáním nacionalistického přesvědčení, že národ představuje základní sociální jednotku tvoříí náš svět. Jak lze vidět v uvedené citaci, Smith akceptuje národ jako sociální jednotku. Proto ne všechny př́pady ztotožnění společnosti s národním státem lze pokládat za prŕípady metodologického nacionalismu ve Smithově smyslu.

Herminio Martins pokládá metodologický nacionalismus (tj. společnost pojímanou jako uzavřené národní společenství) a princip imanentní změny za dva oddělené teoretické problémy, zatímco Smith tyto zamlčené předpoklady sociologické teorie sjednocuje. To ústí do nápaditého vymezení metodologického nacionalismu: podle interpretativní strategie uplatňované Smithem můžeme hovořit o metodologickém nacionalismu pouze $v$ tom prípadě, kdy někdo chápe společnost $\mathrm{z}$ hlediska národního společenství a zároveň pojímá tato sociálněnárodnostní společenství, jako by šlo o vnitřně rostoucí jednotky. Překonat metodologický nacionalismus znamená pro Smitha nutnost opustit teorii imanentní sociální změny. Přesněji řečeno, pokud někdo nebuduje teoretickou koncepci sociálních jednotek na modelu endogenní sociální změny a pokládá národy jen za jednu ze sociálních jednotek našeho světa, pak ho nelze podle logiky Smithovy teorie odsuzovat jako metodologického nacionalistu.

Základní dilema ve Smithově př́padě představuje jeho teoretický předpoklad, podle něhož nacionalismus spočívá $\mathrm{v}$ něčem víc než $\mathrm{v}$ pouhé viře $\mathrm{v}$ existenci národů. A naopak víra v Národ není dostatečnou podmínkou nacionalistického myšlení. Ve stejné knize (Smith 1979), v níž pojednává o vlivu sjednocení státu a národa na sociální vědy ve vztahu k fragmentaci světa na národní státy, rozvíjí Smith pojmový rozdíl mezi a) národem jako přirozenou jednotkou historie a b) národem jako historicky specifickým politickým ideálem: „Za ,národním ideálem ' nacionalistických ideologií stojí velmi staré a kvazi-organické formování národa jako kulturní a etnické organizace. $V$ tomto smyslu je rozdíl mezi nějakou etnickou skupinou či lidem a ,národem“ pouze věcí stupně..." (1979: 167). Analytický koncept národa tak podle Smitha odkazuje k základní formě lidského sdružování, která je vymezena dvěma typy vztahů zabarvených etnocentrickými pocity: a) pouty k počátkům a původu stejně jako b) připoutáním $\mathrm{k}$ půdě a $\mathrm{k}$ území. Na druhé straně nacionalismus podle něj spočívá v politizaci národa (Smith 1979: 169). Vytváŕí ideologii zdůrazňující proměnu národa jako kulturní jednotky v politické těleso, tj. v národní stát.

Smith může tvrdit, že jeho teorie není ovlivněna metodologickým nacionalismem, protože nepojímá národy jako sociální jednotky z hlediska teorie endogenní změny, a co víc, 
pokládá národy jen za jeden z typů sociálních jednotek konstituujících náš svět. Nicméně z výše uvedeného je jasné, že ve Smithově pojetí jsou národy něčím víc než jinými sociálními jednotkami. I když se otevřeně staví proti „Zvnitřn̆ujícíc teorii sociální změny, jeho interpretační strategie je nepochybně zasvěcena teoretickému vyprávění o historické imanenci, která ospravedlňuje analytická privilegia propůjčovaná národům a stavějící je nad ostatní sociální jednotky odkazem $\mathrm{k}$ metaforickému kritériu přirozených základů a hlubokých kořenů. ${ }^{11}$ Jednoduše řečeno, navzdory skutečnosti, že se Smith distancuje od politické ideologie nacionalismu a jeho představy sociální změny, teoretické předpoklady jím ustavených analytických kategorií jsou zřetelně spojeny s kulturními imaginací nacionalismu.

\section{Metodologický na cionalismus jako neadekvátní teorie modemity}

Anthony Giddens se ve své knize Tř́lni struktura rozvinutých společností (Class Structure of Advanced Societies) (1973) zabýval otázkou metodologického nacionalismu ve své analýze vztahu mezi národním státem a modernitou. Giddens jde za pouhé tvrzení, že metodologický nacionalismus sestává z konceptuálního ztotožnění společnosti s národním státem. Jeho kritická argumentace začíná zpochybňováním praxe současné sociologie, která teoreticky chápe národní stát jako vnitřně se vyvíjející a izolovaný celek. Giddens tvrdí, že tento způsob konceptualizace národního státu s sebou nese nereflektované teoretické důsledky pro pojímání modernity v hlavním proudu sociologie. Jinými slovy pojednává z pohledu metodologického nacionalismu současně konceptualizaci společnosti a teorii národního státu. Výrazem metodologického nacionalismu totiž není pouhé ztotožnění společnosti s národním státem, ale to, že toto ztotožnění pojímá metodologicky nacionalistickým způsobem.

Giddens se obává zejména hegemonie př́istupu metodologického nacionalismu k modernitě. V jeho základech nachází sociologicky neadekvátní, nacionalistickou koncepci národního státu. Na scénu jeho kritiky nedostatečného pojetí národního státu v sociologii pak vstupuje koncept společnosti: národní stát pojatý metodologicko nacionálním způsobem se zakládá na (a) historické absenci rozpoznání ústředních institucionálních rysů moderního státu, (b) sociologicky nepřesné teorii společnosti. Pojetím národního státu se Giddens ve svém díle zabýval také v 80. letech 20. století, přičemž nejvýrazněji se mu věnoval ve své knize Národní stát a násilí (Nation-State and Violence) (1985). Tam zastával názor, že moderní společnosti jsou ve skutečnosti národními státy a fungují v rámci celého systému národních států. Avšak jako nepřijatelnou shledal pozici některých sociologů, kteří považují společnosti za ,jasně vymezené systémy se zřetelným a snadno identifikovatelným souborem odlišujících znaků“ (1985: 17). ${ }^{12}$

11 Mohu uvést jiný důkaz: „V tomto pojetí nacionalismu se nacionalismus stává něčím víc než jen masovou emocí založenou na etnocentrismu... stává se ideologií samotnou, rivalem ostatních politických ideologií, přesto rozlišitelný svou pevnou základnou v ,přirozené‘ masové emoci, která vždy doprovází etnické sdružování... Nacionalismus je přirozeným dědicem neporušené tradice, kterou hledá, aby ji použil a nasměroval pro své vlastní politické cíle“ (Smith 1979: 168).

12 Stjepan Mestrovic (1998: 179) ve své podrobné interpretaci Giddensova sociologického díla tvrdí, 
Pro Giddense, stejně jako pro Smithe, spočívá hlavní problém s metodologickým nacionalismem $\mathrm{v}$ jeho předpokladu interní dynamiky národního státu/společnosti. V tomto smyslu byly národní státy autonomní ohraničené jednotky ovládané vlastní vnitřní dynamikou. Giddens (1973: 265) př́mo říká: „Primární jednotkou sociologické analýzy, sociologovou ,společností - přinejmenším ve vztahu k industrializovanému světu -, vždy byl a musí být administrativně ohraničený národní stát. Ale ,společnost ${ }^{\star} \mathrm{v}$ tomto smyslu nebyla nikdy izolovaným ,vnitřně se vyvíjejícím“ systémem, který běžně předpokládala sociologická teorie.“ Giddens (1973: 265) je kritický vůči sociologickému sklonu uvažovat o sociální změně skrze myšlenku vývoje a „,rozvoje“ endogenních vlivů uvnitř určité společnosti“. Takovýto vývojový pohled na sociální změnu pracuje se striktním oddělením vnitřních a vnějších faktorů sociální dynamiky. Vnější faktory, lokalizované vně administrativně ohraničené jednotky národního státu, se z této perspektivy zdají být ve vztahu $\mathrm{k}$ vývoji společnosti zcela nahodilé. Tyto externí faktory získávají analytický status nahodilých faktorů souběžné s tím, že vývojová perspektiva s nimi nakládá jako faktory tvořícími prostředí, čemu se společnost musí přizpůsobit.

Giddens (1973: 265) odkrývá dva epistemologické zdroje endogenního náhledu na sociální změnu: (a) používání organických analogií a (b) předpoklad důležitosti technologické a ekonomické organizace společnosti. Používání organických metafor při sociologické konceptualizaci sociální změny vede $\mathrm{k}$ domněnce, že se moderní společnost mění podobně, jako když mladý organismus rozvíjí svi̊j potenciál v procesu růstu. V této antropomorfní vizi moderní společnosti je změna, a tedy modernizace představována jako proces předvídatelného dozrávání. Na straně druhé endogenní vize je svázána s přeceňováním vnitřních společenských faktorů $\mathrm{v}$ důsledku domněnky, že procesy změny, které společnost zasahují, jsou předurčeny její technologickou a ekonomickou organizací. V tomto pojetí se společnosti mění různě $\mathrm{s}$ ohledem na to, $\mathrm{v}$ jakém stádiu technologického a ekonomického rozvoje se nacházejí, a proto je nejsilnějším motorem sociální změny technologická a ekonomická organizace společnosti.

Jakou vhodnější konceptualizaci Giddens nabízí jako východisko z této situace? Navrhuje poměrně mírnou strategii změny teoretického postoje: doplnění kritizovaných teorií. Sociologové musí uznat, že sociální transformace vždy vznikaly a vznikají kombinací interních faktorů vnitřní sociální evoluce a vnějších vlivů. Kromě toho navrhuje analytické rozlišení mezi dvěma typy vnějších vlivů: (a) šírením kultury z jedné společnosti do druhé, přičemž kulturu chápe $\mathrm{v}$ materiálním a ideologickém smyslu, (b) politickým vlivem jedné společnosti na druhou, přičemž tento vliv má podle něj podobu ovládání nebo podřizování.

Nerozhodná kritika metodologického nacionalismu u Anthonyho Giddense nabývá teoretického významu především díky tematickému kontextu, v němž byla vyslovena. Jeho hlavním terčem nebyl politický nacionalismus jako v př́ípadě Anthonyho Smithe, ale ty sociologické teorie modernity, které hovoří o zastaralosti národního státu. Dávno předtím, než na scénu vstoupil sociologický diskurs o globalizaci, Giddens (1973: 264) píše o důsledcích

že Giddens ve skutečnosti nebyl schopen opustit modernistické vzorce společnosti. Zachází se společnostmi, jednotlivci, národními státy a dokonce i s modernitou systematickým způsobem. Jak jednotlivci, tak národní státy jsou pro Giddense pevně ohraničeny, hledají řád a fungují racionálně. 
pokroku v dopravě a „dramatickém vývoji způsobů komunikace a šíření informace, které dovolí virtuálně okamžitý kontakt mezi místy na opačném konci světa“. Zatímco poznamenává, že tyto př́pady moderního vývoje v komunikaci a dopravě vedou k vymizení předcházejících sociálních významů času a prostoru, tvrdí, že spolu s těmito vlivy „utváření nadnárodních ekonomických a politických sítí a stále vzrůstající mezinárodní charakter megakorporací... zasáhne do fungování národního státu, neznamená [však] konec jeho existence, ale v určitém smyslu přispívá k posílení jeho autonomie“ (Giddens 1973: 264).

Giddens ve své práci během osmdesátých let pokračuje v obraně významu národního státu pro jakoukoli sociologickou teorii modernity. Ve své knize Současná kritika historického materialismu (A Contemporary Critique of Historical Materialism), vydané v roce 1981 (Giddens 1995: 12, 182-202, 210), tvrdí, že historický vztah mezi národním státem a kapitalismem nebyl náhodný, ale naopak, moderní národní státy a moderní kapitalismus se vytvářely ve vzájemném propojení. Vznik národního státu a celosvětového systému národních států by byl nemožný bez rozšíření kapitalismu. Vzato z opačné strany, vývoj kapitalistických společností byl rozhodujícím způsobem utvářen institucionální schopností národního státu nahrazovat města jako „kontejnery moci“, to znamená koncentrovat a akumulovat veškeré dostupné zdroje dané společnosti/daného území.

Teritorialita tedy hraje v Giddensově teorii národního státu rozhodující roli: stát není nic jiného než ,administrativní aparát, jehož moc se rozprostírá nad přesně definovaným a ohraničeným územím“ (1995: 13). Je však velmi důležité, abychom chápali toto teritorium jako produkt institucionálního vymezení. V tomto bodě musím upozornit na vážnou teoretickou nesrovnalost, která se vyskytuje v Giddensově konceptualizaci jak národního státu, tak jeho teritoriální povahy. Na jedné straně trvá Giddens na rozlišení mezi národnostní povahou národního státu a nacionalismem mas: „Co dělá v mé definici ,národ“ nutným prvkem ,národního státu“ není existence nacionalistického cítění (at’ už může být jakkoli silné), ale sjednocení administrativního aparátu..." (1995: 13). Nacionalismus je pro Giddense něčím z oblasti kultury a odkazuje $\mathrm{k}$,,symbolům nebo přesvědčením, které připisují pospolnou zkušenost členům dané regionální, etnické nebo jazykové kategorie - která se může ale nemusí blížit územnímu vymezení národního státu“ (1995: 13). V tomto smyslu se nacionalismus pokládá za specificky moderní způsob vyjádření pocitů, které vyvolávala vykořeněnost každodenního života, v němž se rozpadaly tradice. V protikladu k tomuto kulturnímu pojetí nacionalismu je národ ve vztahu k národnímu státu něčím, co „sjednocuje“ administrativní aparát, přičemž toto sjednocení se nezakládá na pocitech. Podobně i národní území národního státu je vymezeno jiným způsobem než kulturně, to znamená nikoli prostřednictvím symbolů, přesvědčení a pocitů.

Na straně druhé zakládá Giddens svou teorii strukturace na situované povaze sociálních praktik, čili na „svázanosti“ s časem a prostorem. V návaznosti na Heideggera tvrdí, že čas a prostor by se neměly pokládat za nádoby objektů a událostí. Nicméně heideggerovská konceptualizace teritoriality založená na fenomenologii a hermeneutice předpokládá teoretický význam intersubjektivity jak v prŕpadě praktik, tak zkušeností. Čas a prostor mohou tvořit část sociální reality jen skrze intersubjektivně sdílené praktiky a zkušenosti časovosti a prostorovosti. Představovat si národní území bez toho, abychom vzali v úvahu zkušenosti těch, kdo ho intersubjektivně konstituují, je proto zavádějící. 
Nejdůležitějším teoretickým problémem spojeným s metodologickým nacionalismem je proto otázka, kdo konstituuje „národní“ teritorium. Giddensova interpretativní strategie se snaží obejít zkušenost (jejím redukováním na pocity) zdůrazňováním významu praktik. Přesněji řečeno, Giddens uznává jen význam specifických praktik administrativního aparátu, který produkuje časoprostor v určité konkrétní racionální formě. Giddens pojímá časovost a prostorovost jako institucionalizované formy produkce, a snaží se tak reinterpretovat Heideggerovu teorii svázanosti prostoru a času v Marxově institucionální perspektivě. Národní stát se tedy v jeho koncepci stává jakýmsi výrobním zařízením, které produkuje standardizované sociální formy času a prostoru. Jak jsou tyto „produkty“ zakoušeny subjekty není v této perspektivě vůbec důležité.

Praktiky produkující národní území se však nemohou odehrávat bez sociálních aktérů, kteří zakoušejí čas a prostor z národního hlediska. Je sice jasné, že z teoretické perspektivy modernity nemusí být administrativní aparát nutně sjednocen prostřednictvím nacionalistických pocitů (alternativu zde představuje moderní ideál racionální byrokracie založený na profesní loajalitě), nicméně praktiky časového a prostorového vytváření národního území nelze plně oddělit od zkušeností modernity, které jsou vnitřně propojeny s nacionalistickou imaginací a pocity národnostní př́slušnosti. Giddensova snaha rozvinout kritiku metodologického nacionalismu, která do velké míry vychází z teoretického předpokladu možnosti konceptuálně oddělit a nespojovat nacionalismus a národní stát, je nepřesvědčivá především proto, že nedostatečně teoreticky podchycuje kulturní procesy vytváření významu.

Giddensova kritika metodologického nacionalismu představuje pokus vypracovat sociologickou teorii národního státu, která by se nezakládala na nacionalistickém pojímání státu. Podobně jako Giddens ve své kritice i teoretický rozbor současných forem transnacionalismu stojí před dilematem mezi odmítáním konceptuálního rámce nacionalismu jako analyticky nepřijatelného na jedné straně a přehližením historické role, kterou hrály nacionalistické způsoby myšlení, vyjadřování a prožívání národního státu při vytváření institucionální a diskursivní reality národního státu na straně druhé. Je zapotřebí, abychom dekódovali text národního státu, aniž bychom akceptovali nároky nacionalistického jazyka, v němž je tento text napsán, na pravdu; ale zároveň bychom neměli zapomínat na skutečnost, že text o národním státu není psán nacionalistickým jazykem náhodou.

\section{Dvě verze kritiky}

Wagner (1994) prohlašuje, že hlavní proud sociologie v šedesátých letech 20. století byl „inkoherentní fúzí kvantitativně-empirických technik, funkcionalistického a systémově teoretického uvažování a evoluční sociální teorie modernizace“. Proto není divu, že mezi nejvíce oslavovaná díla následujícího období (let sedmdesátých) patřily úvahy nad stavem sociologie jako vědecké disciplíny (Gouldner 1970; Bourdieu 1977; Habermas 1990 [1970]). Obecně byly kritizovány rozšířené jistoty minulého období, především pojem společnosti jako pevné entity. Jinými slovy objektivistická reprezentace společnosti, která ji pojímala jako strukturálně a funkcionálně predeterminovanou, uzavřenou jednotku, již v sedmdesátých letech ztratila svi̊j nepochybný status. 
Sociologie jako disciplína v sedmdesátých letech 20. století zažívala krizi autority. Souhrnné strukturální a funkcionální koncepce společnosti ztratily svou přesvědčivost tvárí v tváŕ politické a ekonomické krizi konce šedesátých a začátku sedmdesátých let. Avšak skutečnost, že důraz se v této době kladl na radikální zpochybňování teoretických modelů společnosti, měla původ rovněž v reflexivním obratu, který se v raných sedmdesátých letech v sociologii odehrál. Podle Wagnera (1994: 146) se reflexivita do zorného pole sociologů dostala dvěma způsoby: Kvůli zmíněné krizi autority se zdálo v zájmu dalšího pokračování disciplíny nutné reflektovat hlavní sociologické koncepty a teorie. Reflexivita s sebou navíc nesla skepsi vůči objektivismu konceptů hlavního proudu. Tato skepse pak upozornila na reflexivní povahu sociologie jako na její konstitutivní charakteristiku v epistemologickém smyslu, charakteristiku, která se odvozuje od skutečnosti, že sociologové jsou zároveň účastníky a pozorovateli sociální reality. Sociologie se prostě snaží vysvětlovat sociální realitu, v níž už lidé vytvořili své vlastní interpretace. Sociologie v tomto smyslu nemůže ignorovat to, že interpretace aktérů nevyhnutelně vstupují do sociologických konceptů a teorií.

Kritika metodologického nacionalismu zpochybňuje jedno $\mathrm{z}$ nejpevnějších přesvědčení současných sociálních věd: že sociální realita nutně existuje v podobě územně vymezených společností uspořádaných ve státy. Toto přesvědčení zřejmě nesdílejí pouze sociální vědci, ale je prítomno také mezi sociálními aktéry. Podobně jako Martins (1974), který tvrdil, že reflexivní kritika zahrnuje odkrývání konceptuálních vztahů mezi praktickým věděním, které sociální aktéri používají ve svém žitém světě, a analytickým věděním, které sociologie užívá k výzkumu sociální reality, Ulrich Beck (2004: 139) ř́ká, že existuje dvojí spojení mezi „národním hlediskem“ sociálních aktérů a „metodologickým nacionalismem“ sociálních vědců. Na epistemologické úrovni se národní hledisko sociálních aktérů - tedy rovnítko mezi společností a národním státem - proměňuje $\mathrm{v}$ metodologický nacionalismus, když se stává metodou vědeckého pozorování. Na druhé straně mezi těmito dvěma hledisky existuje také historická spojitost. Národ, společnost a stát se stávají sociologickými pojmy v době vzestupu národního státu.

Sociologie ovládaná metodologickým nacionalismem položila rovnítko mezi ideu společnosti a národního státu. $\mathrm{V}$ tomto smyslu vládne hlavnímu proudu sociologické imaginace představa národního státu (Beck 2002a: 51-54). Beck prohlašuje, že pevnost a soběstačnost národního státu jsou nyní v úpadku a že tato historická změna vyžaduje od sociologie přezkoumání a nové pojetí sebe sama jako transnacionální vědy. Nicméně tato proměna sociologie si žádá osvobození sociologické imaginace od vlivů metodologického nacionalismu. Beck výslovně formuloval výzkumnou strategii nazvanou „metodologický kosmopolitismus“, která usiluje o osvobození sociálních věd od staré „teorie společnosti jako nádoby“ a dalších „zombie kategorií“ metodologického nacionalismu. Jeho emancipační program chce do zorného pole sociálních věd přivést jevy, které byly dř́ve z dominantní perspektivy metodologického nacionalismu analyticky vyloučeny. Konceptuální rámec metodologického nacionalismu skutečně zakrývá nedávné radikální změny, brání konfrontaci sociální teorie $\mathrm{s}$ empirickou realitou. V tomto smyslu sociální teorie ovládaná metodologickým nacionalismem dokonce vylučuje šanci, že by „se jednota státu a národa mohla rozpustit, rozpadnout nebo že by doznala úplné proměny“ (Beck 2006: 28-29). 
Reflexivní obrat v sociologii v sedmdesátých letech 20. století, včetně radikálního zpochybňování hlavního proudu sociologických koncepcí, také znamenal určitou naději v dobách krize. Tehdejší politická a ekonomická krize dala vzniknout očekáváním, že je nevyhnutelná základní změna v uspořádání společnosti. Podobně pak tento obrat poskytl teoretický kontext pro re-konceptualizaci společnosti, která se $\mathrm{v}$ době krize zdála být nutností.

I kdyby nic jiného, může nám rekonstrukce počátků kritiky metodologického nacionalismu odhalit skutečnost, že tento kritický diskurs vždy osciloval mezi teoretickými/epistemologickými a historickými/empirickými verzemi kritiky. Naše koncepty mohou být neadekvátní, protože se realita změnila, avšak mohou být neadekvátní také proto, že jsou teoreticky nedostatečné. Např́klad v rámci debaty o globalizaci byly zpochybněny státo-centrické způsoby analýzy díky tvrzení, že procesy globalizace nově uspořádaly klíčové vlastnosti národních státu. Přesněji řečeno, diskurs globalizace doplnil teoretickou/epistemologickou kritiku metodologického nacionalismu historickými/empirickými argumenty, které poukazovaly na nové uspořádání územních kvalit národních států. Oba druhy těchto argumentů ukazují, že teritoriální model do sebe uzavřených, státně vymezených společností - geografických nádob ekonomických, politických a kulturních vztahů - je vysoce problematický. Zatímco druhý $\mathrm{z}$ argumentů tvrdí, že územní model společnosti se stal problematickým dnes, první z nich říká, že byl ve skutečnosti problematický vždy.

Wallerstein v Odmýšlení sociální vědy (Unthinking Social Science) (1991) - které staví na reflexivních sociologických myšlenkách 70. let 20. století, rekonstruuje epistemologii sociální vědy 19. století a analyzuje sociální dějiny této epistemologie - tvrdí, že analýzy sociálních věd byly špatně zaměřené, nebot' dva z jejich základních konceptů byly neadekvátní: vývoj a kategorie času a prostoru (Wallerstein 1991: 39-148). Vývoj pojímaný v podobě rozvoje je podle něj ústřední ideologickou kategorií éry po roce 1945. Teoretická relevance této analytické kategorie není navíc omezená pouze pro její ideologickou povahu, ale také proto, že pojímá společenskou změnu reduktivně, pouze z hlediska průmyslové revoluce. Nedávné užívání kategorií času a prostoru v sociálních vědách je rovněž charakterizováno omezenou epistemologickou reflexivitou. Pojmy času a prostoru jsou totiž stále prezentovány, jako by byly samozřejmými skutečnostmi, nikoliv pojmy. Tento způsob myšlení brání potenciálu sociálních věd klást otázky relevantní vzhledem $\mathrm{k}$ současné realitě.

\section{Závěry}

Naznačil jsem, že kritické teorie transnacionalismu se musí zaměřit na transnacionální jevy (tzn. transnacionální migraci, globalizaci) a zkoumat způsoby, jak jsou v sociálních vědách teoreticky chápány národní jevy (imigrace, národní stát). První záměr napomůže pochopit, jak sociální podmínky a kulturní procesy utvářejí transnacionalitu. Druhý pak umožňuje teoriím transnacionalismu uchopit způsob, kterým jsou vztahy ovládání zakódovány do konceptuálních rámců a teoretických hledisek akademického diskursu. Věnujeme-li pozornost také rekonstruktivní interpretaci sociálních věd, kritické teorie transnacionalismu mohou upustit od módní konceptualizace transnacionality jako něčeho radikálně nového, jako vznikajícího produktu globalizace. 
Své volání po kritice metodologického nacionalismu jsem vedl v mírně polemickém duchu. To neznamená, že bych současné snahy opustit metodologický nacionalismus chtěl snižovat. Jestliže má sociologie transnacionalismu zůstat inovativní větví poznání, pak by měla být schopna podpořit reflexivní analýzu vlastních kritických projektů. Významně v tomto ohledu přispěli Ulrich Beck nebo Manuel Castells, kteří tvrdí, že metodologický nacionalismus byl v současnosti zpochybněn novou zkušeností vzájemné závislosti. Neméně důležité pak je dát prostor teoretickým dilematům, které kritika metodologického nacionalismu produkuje. Krokem tímto směrem je hermeneutická rekonstrukce prvních pokusů o analýzu metodologického nacionalismu uskutečněných v sedmdesátých letech 20 . století.

Rekonstrukce, kterou jsem provedl, vyzdvihla tři znaky této rané kritiky: za prvé soustředila se na argument, že metodologický nacionalismus je nutně spojen s konkrétní teorií sociální změny, která zdůrazňuje imanentní společenskou dynamiku. Za druhé věnovala pozornost teoretickému dilematu plynoucímu z konceptualizace národů jako sociálních jednotek. Jestliže považujeme národ za sociální jednotku, můžeme se pokusit vyhnout se metodologickému nacionalismu explicitní distancí od politické ideologie nacionalismu a jeho evoluční vize historické změny. Pokud však redukujeme nacionalismus na politickou ideologii, můžeme přehlédnout jeho kognitivní kulturní rozměr. Následkem toho hrozí opomenutí role, kterou kulturní symboly nacionalismu hrály při ustavování metodologického nacionalismu. Za třetí analýza se věnovala teoretickému dilematu konceptualizace národního státu mimo rámec metodologického nacionalismu. Jestliže zavrhneme konceptuální rámec nacionalismu jako nepřijatelný, pak můžeme mít sklon považovat nacionalismus za něco iracionálního, spojeného s city a zkušenostmi a jejich projevováním, tj. za irelevantní kulturní jev. Ovšem když snížíme nacionalismus na povrchně pojímanou kulturní záležitost, snadno nám unikne role, kterou nacionalistické způsoby myšlení a proživání hrály při institucionalizaci národního státu.

Přístup, který vezme vážně rekonstruktivní interpretaci rané formy kritiky metodologického nacionalismu, pak plně rozpozná důležitost teoretického uvažování v sociologii a pojme otázku metodologického nacionalismu jako otázku konfliktu mezi alternativními teoretickými rámci, které nemohou být jednoduše zavrženy nebo potvrzeny s odkazem na empirickou realitu nebo tváŕí v tvář proklamovanému nástupu nové dějinné epochy.

\section{Literatura}

APPADURAI, Arjun. Modernity at Large: Cultural Dimensions of Globalization. 3 vyd. Minneapolis: University of Minnesota Press, 1997. 224 s. ISBN 0-81662-793-2.

BASCH, Linda G. Nations Unbound: Transnational Projects, Postcolonial Predicaments, and) Deterritorialized Nation-States. 1. vyd. London: Routledge, 1994. 360 s. ISBN 2-88124-630-3.

BECK, Ulrich. Cosmopolitical Realism: On the Distinction between Cosmopolitanism in Philosophy and the Social Sciences. Global Networks, 2004, roč. 4, č. 2, s. 131-156. ISSN 1470-2266.

BECK, Ulrich. The Cosmopolitan Vision. Cambridge: Polity, 2006. 216 s. ISBN 0-74563-399-4. 
BECK, Ulrich. The Terrorist Threat: World Risk Society Revisited. Theory Culture Society, 2002, roč. 19, č. 4, s. 39-55. ISSN 0263-2764.

BOURDIEU, Pierre. Outline of a Theory of Practice. Cambridge: Cambridge University Press, 1977. 224 s. ISBN 0-52129-164-X.

BRENNER, Neil. Beyond state-centrism? Space, territoriality, and geographical scale in globalization studies. Theory and Society, 1999, roč.28, č. 1, s. 39-78. ISSN 0304-2421.

CAMUS, Albert. The Rebel. Harmondsworth: Penguin Books, 1962. $310 \mathrm{~s}$.

CASTELLS, Manuel. The Power of Identity. 1 vyd. Malden, MA: Blackwell Publishers, 1997. 460 s. ISBN 1-55786-874-3.

DELEUZE, Gilles. A Thousand Plateaus: Capitalism and Schizophrenia. London: Continuum, 1988. 629 s. ISBN 0-81661-401-6.

FOUCAULT, Michel. Different Spaces. In FOUCAULT, M. Aesthetics, Method, and Epistemology: Essential Works of Michel Foucault 1954-1984 v. 2. London: Penguin, 2000, s. 175-185. ISBN 0-14025-956-2.

FOUCAULT, Michel. Questions on Geography. In CRAMPTON, J. W., ELDEN, s. Space, Knowledge and Power: Foucault and Geography. Aldershot: Ashgate, 2007, s. 173-182. ISBN 0-75464-655-6.

GIDDENS, Anthony. Class Structure of the Advanced Societies. S.1.: Hutchinson, 1973.

GIDDENS, Anthony. The Nation-State and Violence. A Contemporary Critique of Historical Materialism vol. 2. London: Polity, 1985. ISBN 0-52006-039-3.

GOULDNER, Alvin Ward. The Coming Crisis of Western Sociology. New York: Basic Books, 1970. 528 s. ISBN 0-43582-150-4.

GUPTA, Akhil; FERGUSON, James (eds.) Culture, Power, Place: Explorations in Critical Anthropology. Durham, N.C: Duke University Press, 1997. 376 s. ISBN 0-82231-940-3.

HABERMAS, Jürgen. On the Logic of the Social Sciences. 1vyd. Cambridge: Polity Press, 1990. 236 s. ISBN 0-26258-104-3.

HABERMAS, Jürgen. Reconstruction and Interpretation in the Social Sciences. In Moral Consciousness and Communicative Action. Cambridge, Mass: MIT Press, 1990, s. 21-42. ISBN 0-26208-192-X.

HABERMAS, Jürgen. What is Universal Pragmatism. In Communication and the Evolution of Society. Cambridge: Polity Press, 1991, s. 1-68. ISBN 0-74560-846-9.

JAMESON, Fredric. Postmodernism, or, The Cultural Logic of Late Capitalism. 6. vyd. Durham: Duke University Press, 1995.

KEARNEY, Michael. Borders and Boundaries of State and Self as the End of Empire. Journal of Historical Sociology, 1991, roč. 4, č. 1, s. 52. ISSN 0952-1909.

LEFEBVRE, Henri. The Production of Space. Oxford: Blackwell, 1991. 468 s. ISBN 0-63118177-6.

LEVITT, Peggy; JAWORSKY, B. Nadya. Transnational Migration Studies: Past Developments and Future Trends. Annual Review of Sociology, 2007, roč. 33, č. 1, s. 129-156. ISSN 0360-0572.

LEVITT, Peggy; GLICK SCHILLER, Nina. Conceptualizing Simultaneity: A Transnational Social Field Perspective on Society. International Migration Review, 2004, roč. 38, č. 3, s. 1002-1039. ISSN 0197-9183. 
MARTINS, Herminio. Time and Theory in Sociology. In REX, J. (eds.) Approaches to Sociology. An Introduction to Major Trends in British Sociology. London, Boston: Routledge, 1974, s. 246-294. ISBN 0-71007-825-0.

MEŠTROVIĆ, Stjepan G. Anthony Giddens: The Last Modernist. 1. vyd. London: Routledge, 1998. 256 s. ISBN 0-41509-572-7.

POLKINGHORNE, Donald. Methodology for the Human Sciences. Albany: SUNY Press. 1983. 349 s. ISBN 0-87395-664-8.

SMART, Barry. Sociology, Phenomenology and Marxian Analysis. London: Routledge, 1976. 240 s. ISBN 0-71008-373-4.

SMITH, Anthony D. Nationalism in the Twentieth Century. Oxford: Martin Robertson, 1979. 257 s. ISBN 0-81477-803-8.

SMITH, Anthony D. Nationalism and Classical Social Theory. The British Journal of Sociology, 1983, roč. 34, s. 19-38. ISBN 0007-1315.

SMITH, Anthony D. The Concept of Social Change: A Critique of the Functionalist Theory of Social Change. 1. vyd. London: Routledge, Kegan Paul, 1973. 208 s. ISBN 0-71007697-5.

SOJA, Edward W. Postmodern Geographies: The Reassertion of Space in Critical Social Theory. 8. vyd. London: Verso, 1989. 266 s. ISBN 0-86091-936-6.

VIRILIO, Paul. Speed and Politics. 2. vyd. Los Angeles: Semiotext(e), 2007. 174 s. ISBN 1-58435-040-7.

WAGNER, Peter. A Sociology of Modernity: Liberty and Discipline. London: Routledge, 1993. 288 s. ISBN 0-41508-186-6.

WALLERSTEIN, Immanuel Maurice. Unthinking Social Science: The Limits of NineteenthCentury Paradigms. Cambridge: Polity Press, 1991. 286 s. ISBN 0-74560-876-0.

WIMMER, Andreas; GLICK SCHILLER, Nina. Methodological nationalism and beyond: nation-state building, migration and the social sciences. Global Networks, 2002, roč, 2, č. 4, s. 301-335. ISSN 1470-2266.

WIMMER, Andreas; GLICK SCHILLER, Nina. Methodological nationalism and the study of migration. European Journal of Sociology, 2002, roč. 43, s. 217-240. ISSN 0003-9756.

WIMMER, Andreas; GLICK SCHILLER, Nina. Methodological Nationalism, the Social Sciences, and the Study of Migration: An Essay in Historical Epistemology. International Migration Review, 2003, roč. 37, č. 3, s. 576-610. ISSN 0197-9183.

\section{Autor}

Csaba Szaló působí na Katedře sociologie Fakulty sociálních studií Masarykovy univerzity v Brně, kde se zabývá kulturní sociologií. Jeho výzkumné aktivity se zaměřují na proces kulturní asimilace a sociální konstrukce identit. Je autorem knihy Transnacionální migrace: Proměny identit, hranic a vědění o nich (Brno: CDK 2007).

Kontakt: szalo@fss.muni.cz 